\title{
Antiphospholipid-Protein Antibodies
}

\author{
-A Paradigm for Antibody-Mediated Thrombosis-
}

\author{
Douglas A. TRIPLETT, M.D.*
}

\begin{abstract}
Antiphospholipid-protein antibodies (APA) are a family of immunoglobulins which recognize a number of plasma proteins that bind to activated phospholipid membranes. Among these plasma proteins are : $\beta 2$ Glycoprotein I ( $\beta 2 \mathrm{GPI}$ ), prothrombin, Annexin $\mathrm{V}$, and other vitamin $\mathrm{K}$ dependent proteins (e.g., factor $\mathrm{X}$ ). APA have been associated with venous and arterial events as well as recurrent spontaneous abortion (RSA). It is estimated that 8 to $14 \%$ of venous thrombosis is secondary to the presence of APA. APA are the most common cause of acquired thrombophilia. The concept of antibody-mediated thrombosis is now widely accepted.

The laboratory diagnosis of APA requires the use of coagulation-based tests to identify lupus anticoagulants (LA) and ELISA assays to identify anticardiolipin antibodies (ACA). The importance of testing for antibodies to $\beta 2$ GPI is now well recognized. Antibodies to $\beta 2$ GPI are more specific in identification of patients at risk for thrombosis.
\end{abstract}

Key words : anticardiolipin, lupus anticoagulant, thrombosis

\section{Introduction}

Antiphospholipid-protein antibodies (APA) are a family of immunoglobulins which have been defined by in vitro laboratory tests (Table 1) ${ }^{12)}$. The Immunoglobulins may be IgG, IgM, or IgA isotypes. Individual patients often have a mixture of isotypes. Recently, the concept of these antibodies having specificity for phospholipids has been challenged. The work of McNeil et al., Galli et al., and Matsuura et al. demonstrated that anticardiolipin antibodies (ACA) are not directed against cardiolipin but instead appear to recognize a plasma protein: $\beta 2$ Glycoprotein I ( $\beta 2 \mathrm{GPI})^{3) 4) 5}$. Following these initial observations, Bevers and colleagues found lupus anticoagulants (LA) recognize human prothrombin rather than phospholipids ${ }^{6}$. Both ACA and LA recognize specific plasma proteins when they are bound to activated phospholipid (PL) membranes in vivo (e.g., perturbed endothelium, platelets, monocytes). Presumably, these PL-binding proteins when reacting with

Table 1 Antiphospholipid Antibodies (APA)

I) Lupus Anticoagulants

II) Anticardiolipin Antibodies

III) Reagin

IV) Specific Antibodies to Anionic Phospholipids Antiphosphatidylserine Antiphosphatidic Acid Antiphosphatidylinositol

V) Specific Antibodies to Neutral Phospholipids Antiphosphatidylethanolamine

* Director, Midwest Thrombosis and Hemostasis Laboratories, Muncie, Indiana. Professor of Pathology and Asistant Dean, Indiana University School of Medicine.

The 20th Congress of the Japanese Society of Thrombosis and Hemostasis 
Table 2 APA Classification

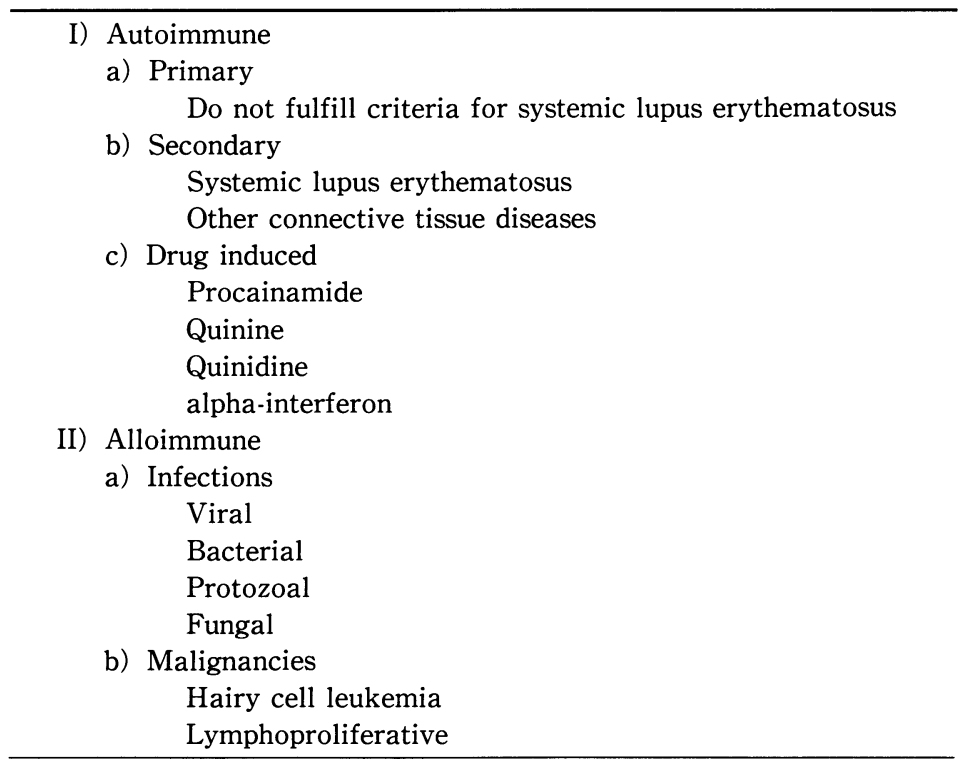

activated PL membranes expose neoepitopes. The subsequent immunologic response to exposure of the neoepitopes results in LA and ACA formation. In vitro test systems using "high sensitivity" microtiter plates relay on the same phenomenon when testing for antibodies to $\beta 2$ GPI or human prothrombin. With the realization that APA, in fact, recognize proteins reconfigured on PL surfaces, a more accurate name for this family of antibodies is antiphospholipidprotein antibodies (APA).

APA may be found in a variety of different clinical settings. In patients with underlying autoimmune disease (e.g., systemic lupus erythematosus,, rheumatoid arthritis, etc.) APA are often detected. The presence of these antibodies in autoimmune disease has been linked to a variety of clinical complications including recurrent venous and arterial thromboembolic events, recurrent abortion/ fetal loss, and thrombocytopenia. The antiphospholipid syndrome (APS) is defined by the presence of one or more of the clinical findings noted above together with positive laboratory tests for ACA or LA. However, the criteria required to diagnose APS need to be revised. With the realization that APA target PL-binding proteins, new test systems have been introduced including those which identify antibodies to specific proteins (e.g., $\beta 2$ GPI). Recently, patients with APS have been described who have negative test results for ACA and LA and only demonstrate antibodies to $\beta 2 \mathrm{GPI}^{7)}$.

In addition to autoimmune APA, alloimmune APA have been described following various infections including bacterial, viral, and protozoal agents. Often, alloimmune APA are transient in contrast to persistence typically seen with autoimmune APA. Table 2 summarizes clinical setting of allo-and autoimmune APA. An important characteristic of alloimmune APA is its transient nature. This is in contrast to persistence of APA in autoimmune disease (i.e., persistent 
positivity of laboratory results demonstrated 6-8 weeks after the initial positive test).

\section{Laboratory Detection of APA}

\section{Lupus Anticoagulants}

The term lupus anticoagulants was first proposed by Feinstein and Rapaport in $1972^{8)}$. This term is a misnomer since the vast majority of patients with LA do not have underlying systemic lupus erythematosus (SLE). Many patients with LA are identified immediately following an intercurrent upper respiratory tract infection. These patients do not manifest any of the findings typically seen with APS. Subsequent testing will, in most cases, show disappearance of LA. In many cases, patients positive for LA will also have ACA positivity $(\sim 40 \%)$. Conversely, ACA positive patients, in many cases, do not have an associated LA. These differences may reflect the underlying quantity of antibody present in the patient plasma as well as differences in protein targets and antibody affinity.

Demonstration of LA identifies a patient at increased risk for thromboembolic events as well as recurrent spontaneous abortions

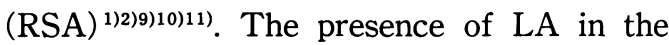
setting of autoimmune disease indicates a relative risk for thrombosis of about seven-to eight-fold increase when compared to controls $^{\left.1{ }^{12}\right)}$. Approximately two-thirds of thromboembolic events are venous and the remaining one-third arterial. Arterial events are typically found in the cerebral circulation ${ }^{13)}$.

The laboratory diagnosis of LA requires a careful sequential series of steps ${ }^{14}$. When a clinician requests the laboratory to rule out LA, it is very important for the laboratory to also do parallel testing for ACA. The presence of persistently positive LA and/or ACA identifies patients at increased risk for thromboembolic events. Patients at risk may be positive for one or both of these tests (more recently, it has been appreciated patients may be negative for both tests and yet still have an increased risk of thrombosis due to anti- $\beta 2$ GPI). Thus, when clinicians request a LA evaluation, they are asking for a comprehensive evaluation for the presence of APA. The laboratory is responsible for performing the appropriate range of tests necessary to identify members of this family of antibodies ${ }^{122}$.

The Lupus Anticoagulant/Phospholipiddependent Antibody Subcommittee of the Scientific and Standardization Committee/ International Society of Thrombosis and Haemostasis (ISTH) has published specific guidelines required to identify LA. Four sequential steps are necessary ${ }^{15}$.

(1) Demonstration of an abnormal phospholipid-dependent coagulation screening test (e.g., Kaolin Clotting Time (KCT), dilute Russell Viper Venom Time [dRVVT], Activated Partial Thromboplastin Time 〔APTT], Textarin Time [TT]) ;

(2) Demonstration the abnormal screening test is due to the presence of an inhibitor (synonym ; circulating anticoagulant) ;

(3) Proof the inhibitor is phospholipiddependent ;

(4) Rule out other coagulopathies (e.g., presence of heparin in the sample, circulating inhibitors such as factor VIII inhibitor).

With increasing recognition of the complexity of the diagnosis of LA, a variety of new test systems have been introduced. In some cases, these tests are complex involving 
incorporation of Steps 1 through 3 into a single system. The Staclot $\mathrm{LA}^{\circledR}{ }^{\circledR}$ is an example of such an integrated approach ${ }^{16}$. Also, dRVVT-based systems have been marketed $^{17}$.

Because of the heterogeneity of the antibody population seen in patients with LA, more than one screening procedure is required. Most often, laboratories choose screening procedures which differ in the portion of the coagulation test system analyzed (e.g., APTT : Intrinsic ; PT : Extrinsic, dRVVT, Final Common Pathway). For instance, the most common combination is a dRVVT and APTT-based systems. Also, the dilute Prothrombin Time (dPT) and Textarin Time have been used ${ }^{18)}$.

\section{Anticardiolipin Antibodies (ACA)}

ACA testing was originally described utilizing solid phase redioimmunoassay ${ }^{19}$. Because this assay system was expensive and also required utilizing radioisotopes, many laboratories quickly moved to ELISA technology ${ }^{20)}$. As discussed earlier, ACA measures anti-

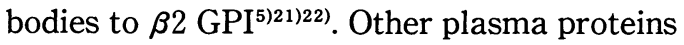
which bind to PLs may be identified in the conventional ACA assay (antibodies to Annexin $\mathrm{V}) . \beta 2$ GPI is a member of the short consensus repeat family of proteins. Physiologically it has anticoagulant properties (inhibits contact activation of the intrinsic pathway, inhibits ADP-induced platelet aggregation, inhibits the prothrombinase reaction). Despite its anticoagulant activities, hereditary deficiency of $\beta 2$ Glycoprotein I is not associated with a predisposition to thrombosis. Presumably, the mechanism of thrombosis associated with antibodies to $\beta 2$ Glycoprotein I requires transmembrane signaling with cellular activation eliciting procoagulant reactions ${ }^{23)}$. As noted above, antibodies to $\beta 2$ GPI are now being evaluated as a means of identifying patients at increased risk for thrombosis. Anti- $\beta 2$ GPI appears to be more specific in identifying patients at risk of thrombosis ${ }^{24)}$. Consequently, many laboratories now perform both conventional ACA and an ELISA assay for antibodies to $\beta 2$ GPI.

\section{Antibody-Mediated Thrombosis}

APA are perhaps the most common acquired cause of thrombophilia. With the recent discovery of hereditary abnormalities leading to thrombophilia (e.g., factor V Leiden, 3' untranslated portion of the prothrombin gene [G20210A], etc.), laboratories are increasingly testing patients for both hereditary and acquired risk factors for thrombosis ${ }^{25}$. The concept of antibodymediated thrombosis has been debated for a number of years. Perhaps the classic example is heparin-induced thrombocytopenia $(\mathrm{HIT})^{26)}$. HIT is associated with antibodies which appear to recognize a complex of heparin-platelet factor 4 (or other plasma proteins such as IL-6) ${ }^{27)}$. This immune complex binds to Fc $\gamma$ IIa receptors on the surface of platelets resulting in activation of platelets and subsequent thrombosis ${ }^{28}$. The pathophysiology of thrombosis seen in the APS is similar. In this case, however, $\beta 2 \mathrm{GPI}$ binds to activated cell membranes (with exposed phosphatidylserine). Antibodies then react with neoepitopes on bound $\beta 2$ GPI. This antigen antibody complex, in turn, activates FcyIIa receptors leading to platelet activation and thrombotic events (Table 3).

Also, APA may inhibit regulatory systems 
Table 3 Similarities of APS \& HIT*

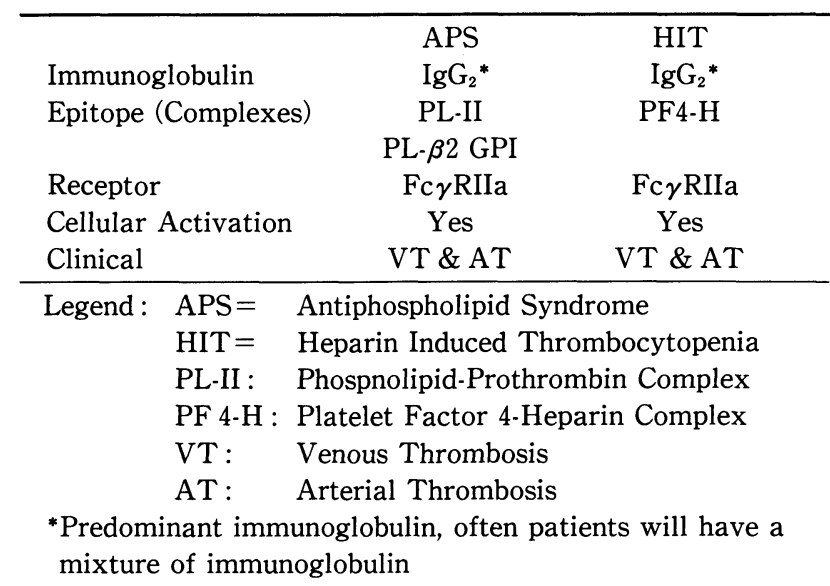

based on membrane localized reactions. The protein $\mathrm{C} /$ protein $\mathrm{S}$ system requires activation of protein $\mathrm{C}$ and subsequent downregulation of factor Va and factor VIIIa by a complex of Activated Protein C (APC) and protein $\mathrm{S}$ on cellular membranes ${ }^{29) 30}$. Antibodies to $\beta 2$ GPI can inhibit this reaction. Again, predisposing to thrombosis.

HIT and the antiphospholipid syndrome represents paradigms of antibody-mediated thrombosis ${ }^{31}$. Other examples include the pathogenicity of antibodies to oxidized LDL and their association with accelerated atherosclerosis $^{32)}$. (Fig. 1) In addition, antibodies to components of the protein $\mathrm{C}$ system have been described (anti-PC and anti-PS as well as antithrombomodulin). Antiendothelial cell membrane antibodies have also been linked to thrombosis. In the coming years, additional mechanisms for antibody-mediated thrombosis will be described. It now appears antibody-mediated thrombosis may be one of the most important acquired mechanisms for thrombosis affecting the arterial and venous circulation.

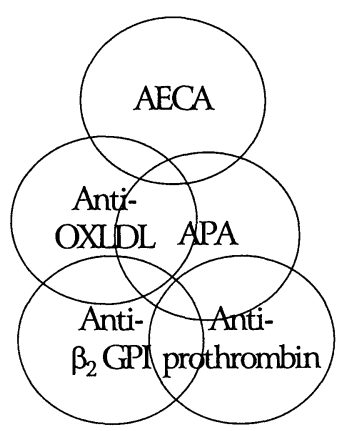

Fig. 1 Antibody Induced Thrombosis

Legend : AECA = Antiendothelial Cell Antibodies

Anti-Ox-LDL $=$ Antibodies to Oxidized Low Density Lipoproteins Anti- $\beta_{2}$ GPI $=$ Antibodies to Beta $_{2}$ Glycoprotein I

Anti-Prothrombin = Antibodies to Prothrombin

APA $=$ Antiphospholipid-Protein Antibodies

\section{References}

1) Triplett DA : Antiphospholipid-protein antibodies: laboratory detection and clinical relevance. Thromb Res $78: 1-31,1995$.

2) Triplett DA : Antiphospholipid antibodies and thrombosis. a consequence, coincidence, or cause? Arch Pathol Lab Med 117 : 78-88, 1993.

3) McNeil HP, Simpson RJ, Chesterman CN, Krilis 
SA: Antiphospholipid antibodies are directed against a complex antigen that includes a lipid binding inhibitor of coagulation : $\beta_{2}$ Glycoprotein I (apolipoprotein H). Proc Natl Acad Sci USA 87 : 4120-4124, 1990.

4) Galli M, Comfurius P, Maassen C, Hemker HC, de Baets $\mathrm{MH}$, van Breda-Vriesman PJC, Barbui T, Zwaal RFA, Bevers EM : Anticardiolipin antibodies (ACA) directed not to cardiolipin but to a plasma cofactor. Lancet 335 : 1544-1547, 1990.

5) Matsuura E, Igarashi M, Igarashi $Y$, Katahira $T$, Nague H, Ichikawa K, Triplett DA, Koike T: Molecular studies on phospholipid binding sites and cryptic epitopes appearing on $\beta_{2}$ Glycoprotein I structure recognized by anticardiolipin antibodies. Lupus 4 : S13-S17, 1995.

6) Bevers EM, Galli $\mathrm{M}$ : Cofactors involved in the antiphospholipid syndrome. Lupus 1 : 51-53, 1992 (editorial).

7) Alarcon-Segovia D, Mestanza M, Cabiedes J, Cabral AR: The antiphospholipid/cofactor syndrome. II. A variant in patients with systemic lupus erythematosus with antibodies to $\beta 2$ Glycoprotein I but no antibodies detectable in standard anticardiolipin assays. J Rheumatol 24:15451551, 1997.

8) Feinstein DI, Rapaport SI : Acquired inhibitors of blood coagulation. Prog Hemost Thromb 1 : 75-95, 1972.

9) Ginsberg JS, Demers C, Brill-Edwards P, Johnston M, Bona R, Burrows RF, Weitz J, Denburg JA : Increased thrombin generation and activity in patients with systemic lupus erythematosus and anticardiolipin antibodies:evidence for a prothrombotic state. Blood 81 : 29582963, 1993.

10) Ginsberg JS, Brill-Edwards $P$, Johnston $M$, et al. : Relationship of antiphospholipid antibodies to pregnancy loss in patients with systemic lupus erythematosus: a cross-sectional study. Blood 80 : 975-980, 1992.

11) Long AA, Ginsberg JS, Brill-Edwards $P$, Johnston M, Turner C, Denburg JA, Cividino A, Andrew M, Hirsh $\mathrm{J}$ : The relationship of anti- phospholipid antibodies to thromboembolic disease in systemic lupus erythematosus: a cross sectional study. Thromb Haemost $66: 520,1991$.

12) Ginsburg KS, Liang MH, Newcomer L, Goldhaber SZ, Schur PH, Hennekens CH, Stampfer $\mathrm{MJ}$ : Anticardiolipin antibodies and the risk for ischemic stroke and venous thrombosis. Ann Int Med 117 : 997-1002, 1992.

13) Ford PM, Brunet D, Lillicrap DP, Ford SE: Premature stroke in a family with lupus anticoagulant and antiphospholipid antibodies. Stroke 21 : 66-71, 1990.

14) Triplett DA : New diagnostic strategies for lupus anticoagulants and antiphospholipid antibodies. Haemost 24 : 155-164, 1994.

15) Brandt JT, Triplett DA, Alving B, Scharrer I : Criteria for the diagnosis of lupus anticoagulants: an update. Thromb Haemost 74 : 1185-1190, 1995.

16) Triplett DA, Barna LK, Unger GA : A hexagonal (II) phase phospholipid neutralization assay for lupus anticoagulant identification. Thromb Hemost 70 : 787-793, 1993.

17) Brandt JT, Triplett DA: The effect of phospholipid on detection of lupus anticoagulants by the dilute Russell viper venom time. Arch Pathol Lab Med 113 : 1376-1378, 1989.

18) Triplett DA, Stocker K, Unger G, Barna L: The textarin/ecarin ratio: a confirmatory test for lupus anticoagulants. Thromb Hemost 70 : 925931, 1993.

19) Harris EN, Gharavi AE, Boey ML, Patel BM, MacWorth-Young CG, Loizou S, Hughes GRV : Anticardiolipin antibodies : detection by radioimmunoassay and association with thrombosis in systemic lupus erythematosus. Lancet 2 :12111214, 1983.

20) Loizou S, McCrea JD, Rudge AC, Reynolds R, Boyle CL, Harris EN : Measurement of anticardiolipin antibodies by an enzyme linked immunosorbent assay (ELISA): standardization and quantitation of results. Clinn Exp Immunol 62 : 738-745, 1985.

21) Roubey RAS : Autoantibodies to phospholipid- 
binding plasma proteins:a new view of lupus anticoagulants and other "antiphospholipid" autoantibodies. Blood 84 : 2854-2867, 1994.

22) Roubey RAS, Eisenberg RA, Harper MF, Winfield JB : "Anticardiolipin" autoantibodies recog. nize $\beta 2$-glycoprotein $I$ in the absence of phospholipid. J Immunol 154 : 954-960, 1995.

23) Roubey RAS, Hoffman $M$ : From antiphospholipid syndrome to antibody-mediated thrombosis. Lancet 350 : 1491-1493, 1997.

24) Sanmarco $M$, Soler $C$ : Heterogeneity of anti- $\beta 2$ Glycoprotein I antibodies. Nouv Rev Fr Hematol 37 : S57-S60, 1995.

25) Rosendaal FR : Risk factors for venous thrombosis: prevalence, risk and interaction. Sem Hematol 34 : 171-187, 1997.

26) Chong $\mathrm{BH}$, Castaldi PA : Platelet proaggregating effect of heparin: possible mechanism for nonimmune heparin-associated thrombocytopenia. Aust N Z J Med 16 : 715-716, 1986.

27) Amiral J, Bridey F, Wolf M, Boyer-Neumann C, Fressinaud E, Vissac AM, Peynaud-Debayle E, Dreyfus M, Meyer D:Antibodies to macromolecular platelet factor 4-heparin complexes in heparin-induced thrombocytopenia : a study of 44 cases. Thromb Haemost 73: 21-28, 1995.

28) Denomme GA, Warkentin TE, Horsewood P, Sheppard J-AI, Warner MN, Kelton JG : Activation of platelets by sera containing IgGl heparindependent antibodies: an explanation for the predominance of the Fc $\gamma$ RIIa "low responder" $\left(\right.$ his $\left._{131}\right)$ gene in patients with heparin-induced thrombocytopenia. J Lab Clin Med 130 : 278-284, 1997.

29) Potzsch B, Kawamura H, Priessner KT, Schmidt M, Seelig C, Muller-Berghaus G: Acquired protein $\mathrm{C}$ dysfunction but not decreased activity of thrombomodulin is a possible marker of thrombophilia in patients with lupus anticoagulant. J Lab Clin Mid 125 : 56-65, 1995.

30) Carreras LO, Forastiero RR : Pathogenic role of antiprotein-phospholipid antibodies. Haemostasis 26 : 340-357, 1996.

31) Triplett DA : Antiphospholipid antibodies, lupus anticoagulants and thromboembolic disease. Haematologica 80 : 122-126, 1995.

32) Vaarala $\mathrm{O}$ : Atherosclerosis in SLE and Hughes syndrome. Lupus 6 : 489-490, 1997. 